\title{
Jurnal Ekonomi Pembangunan (JEP)
}

Vol. 17, No. 02, Desember 2019, pp. 164 174

\section{STEADY STATE CONDITION PREDICTION OF ECONOMIC GROWTH IN EAST JAVA REGION}

\section{Sutikno}

Department of Economics, Faculty of Economics and Business, University of Trunojoyo Madura, Indonesia

\begin{tabular}{|c|c|}
\hline Artikel Info & Abstrak \\
\hline $\begin{array}{l}\text { Article history: } \\
\text { Received } 21 \text { January, } 2020 \\
\text { Revised } 23 \text { January, } 2020 \\
\text { Accepted } 30 \text { January, } 2020 \\
\text { Available online } 31 \text { January, } \\
2020\end{array}$ & $\begin{array}{l}\text { The quality of development of a country or region is not only seen } \\
\text { from the high level of economic growth, but also the higher level of } \\
\text { economic growth produced by people in a country or region. One of } \\
\text { the economic development debates in East Java in the last few } \\
\text { decades is the imbalance of development between regions. This } \\
\text { article focuses its analysis on the value of "stable conditions" districts } \\
\text { / cities in East Java in reducing income disparity between regions. }\end{array}$ \\
\hline $\begin{array}{l}\text { Keyword: } \\
\text { Economic growth; Inequality; } \\
\text { Planning } \\
\text { JEL Classification; O47; } \\
\text { D63; P1 }\end{array}$ & $\begin{array}{l}\text { The analysis in this study is a convergence analysis conducted in } \\
\text { East Java Province using a conditional convergence test with } \\
\text { observations of all districts and cities in East Java. Variable interest } \\
\text { is income per capita. Variable gross fixed investment, net exports, } \\
\text { labor force, capital expenditure, human development index. The } \\
\text { success variable is the average economic growth in 2010-2018. } \\
\text { Whereas the theory underlying all these variables is the Solow- } \\
\text { Swan classical economic growth model. The convergence speed } \\
\text { results explain the convergence speed in East Java Province by } 4.8 \\
\text { percent. Regarding income per capita in developing countries which } \\
\text { must grow at least } 4.8 \text { percent per year for the Java economy to reach } \\
\text { a stable point. The amount of time needed to cover half of the initial } \\
\text { period (half-life of convergence) is } 6.2 \text { years. }\end{array}$ \\
\hline
\end{tabular}

\section{INTRODUCTION}

Economic growth is an indicator of the success of developing a country / region, therefore every country / region seeks to pursue higher economic growth. Economic growth is a process of increasing aggregate income, which implies per capita income if divided by the population of a country / region. So if the uneven economic growth in each region also has implications for per capita income disparities between regions. During this time, economic growth or concentration that is seen from the number of Gross Regional Domestic Product of East Java tends to be concentrated in eight districts / cities, namely: Surabaya City contributes 24.3\%; Gresik Regency 5.82 percent; Sidoarjo Regency 8.55 percent; Malang Raya (Malang Regency, Malang City, Batu City) 8.14\%; Pasuruan Regency 6.13\% and Kediri City 5.7\% which in total accounted for almost 60 percent of the economy of East Java (Central Statistics Agency, East Java, 2019). The data shows that 60 percent of East Java's Gross Regional Domestic Product contributes to the eight regencies / cities. While 30 other districts / cities only contribute 40 percent to Gross Regional Domestic Product. This fact shows that East Java has been experiencing problems with economic growth disparity.

In the theoretical perspective, the gap occurs according to (Capello, 2007) due to two things, namely absolute growth that shows the ability of potential resources in the region and relative growth between regions that can be used to interpret regional inequality and the possibility of convergence in the growth rate or income the average. Disparity in regional economic 
development is a common aspect in the economic activities of a region. This imbalance is basically caused by differences in the content of natural resources and differences in the demographic conditions that exist in each region. As a result of these differences, the ability of a region to drive the process of economic development also becomes different. Similarly, the shift in the composition of the development sectors due to economic activity. Not surprisingly, in each region there are usually developed and underdeveloped regions due to transformation at different speeds.

The neo-classical growth theory predicts the relationship between the level of national economic development and development disparities between regions. This hypothesis became known as the neo-classical hypothesis. In the neoclassical hypothesis, development inequality at the beginning of the process tends to increase. This process will occur until the imbalance reaches its peak. After that, if the development process continues, then the development inequality will gradually decrease. In other words, inequality in developing countries is relatively higher, whereas in developed countries the inequality is relatively lower. Todaro and Smith show development inequality as inverted U-shaped kuznets curves. In Neoclassical theory, per capita income growth has a negative relationship with the initial per capita income level. In this case if in a country or region economically have the same utility and function of production, then a poor country or region can have relatively faster economic growth rates than richer countries or regions, or in a simple sense called convergence (Kuncoro, 2013 ).

The concept of convergence will be used in this study to understand how sooner or later the lagging regions are able to catch up with the laggards from the developed regions. This concept will make it easier for development planners to reduce the level of income disparity between regions, so that it can be understood as a process of underdevelopment of low-income regions to highincome regions. The income gap can be reduced by using a convergence process that is calculated based on real income per capita. Convergence has two different hypotheses that are interrelated. First, stated by (Barro and Sala Martin, 1992) using the neoclassical growth model. One important aspect of this model is analyzed and analyzed as an empirical hypothesis of convergence. In a closed economy the level of growth per capita tends to be inversely related to the level of output or initial income per capita in which regions or countries are poor, the growth of income per capita tends to grow faster than rich regions or countries. Second, there is a hypothesis to catch up or catch up. According to (Abramovitz, 1986) countries with low productivity have great potential to achieve high growth rates. Even so the potential for growth will weaken if the level of productivity growth approaches the level of productivity of the countries that become the benchmark. This indicates the process of catching up.

(Lall and Yilmaz, 2001) observed the convergence of economic growth in 48 American states during the period 1969-94. Government policy variables that are strongly suspected to help the process of convergence tendency 
mechanism are public investment and human capital expenditure by the federal government in the state. The analysis shows that public investment and human capital do not support the acceleration of convergence, but more because of the spillover effect between regions. Meanwhile (Milla and McGuire, 2001), observed assistance from the European Union that was distributed by the Spanish government to local governments together with domestic intergovernmental transfers. The time period of this study, namely 1977-81 (the period before there was assistance from the European Union) and 1989-92 (the period after there was assistance from the European Union). Evaluating data from 17 local governments, they concluded that assistance from the European Union did not improve economic performance in poor regions of Spain.

(Riatu, 2002) examined the effect of intergovernmental transfers on regional economic performance in the $1993-98$ period. The economic variable used as an indicator is private consumption expenditure which has the largest portion in the formation of regional Gross Regional Domestic Product. The results of this study concluded that in general intergovernmental transfers were able to exert positive and effective influence in reducing disparities between regions. Meanwhile (Mohtar Rasyid, 2017), analyzes the growth profile between regencies / cities in East Java for the period 2000-2013. The test results show the convergence hypothesis can be proven quite significant. In other words, there is potential for economic disparities between regions to narrow. From an internal perspective, the economy of East Java can be said to be relatively safe because there are indications that the gap between regions is decreasing.

In previous studies, the convergence test was only done through the conditional convergence test. This is because absolute convergence is a condition of convergence that assumes that economies between regions have similarities, such as economic structure, saving rates, demographics, and other economic variables, (Barrow and Martin, 2004). However, in reality there are several regions that have diverse economic characteristics, so the alleged absolute convergence process is considered weak. So that the conditional convergence test is done which includes other explanatory economic variables in addition to income per capita.

The convergence analysis conducted in this study uses a conditional convergence test by including variables that have not been present in the previous research model, such as gross fixed investment variables, and net exports. The two research variables are included because they see the condition of economic growth in developed regions in East Java such as Surabaya, Gresik, Sidoarjo. The complete interest variable in this study is income per capita. Variable gross fixed investment, net exports, labor force, capital expenditure, human development index. The dependent variable used is the average economic growth in 2010-2018 and 2011-2018. What underlies all these variables is the Solow-Swan classical economic growth model.

Departing from the conditions of economic growth in East Java and the theoretical basis and empirical studies of several previous studies, this study has

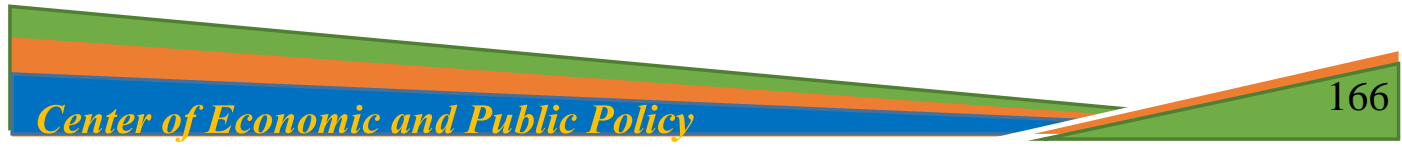


the following objectives: (i) analyze the speed of convergence of East Java's economic growth to get to a steady state and (ii) predict the time (the half -life of convergence) needed by the East Java region towards a steady state.

\section{RESEARCH METHODS}

This study uses panel data analysis, with the main variable in this research being economic growth which is calculated based on the Gross Regional Domestic Product data of 38 districts / cities in East Java in the period 2010-2018. Economic growth is calculated using the average growth of Gross Regional Domestic Product at constant prices (2010) during the study period. The interest variable in this study is income per capita. Variable gross fixed investment, net exports, labor force, capital expenditure, human development index. The main estimation models used in this study are:

$\log$ Git $=\alpha+\beta 1$ LogYit $+\beta \times 2 \log$ PTBit $+\beta 3$ NEit $+\beta 4$ AKit $+\beta 5$ BMit +

$\beta 6$ IPMit + eit

where Git is Regency / municipal Economic Growth, Y is Gross Regional Domestic Product per capita, PTB is gross fixed investment, NE is net export, $\mathrm{AK}$ is labor force, $\mathrm{BM}$ is capital expenditure, HDI is Human Development Index, $\mathrm{i}$ is region, $\mathrm{t}$ is regional is year, $\beta 1, \beta 2, \beta 3, \beta 4, \beta 5, \beta 6$ are regression coefficients and $\mathrm{e}$ is the error term.

After calculating convergence, the next step is to calculate convergence speed. According to (Barro and Sala-I-Martin, 2004) the speed of convergence is important to know because when convergence occurs the faster it indicates that the economy will be getting closer to steady-state conditions. Conversely, if convergence is very slow, the economy will increasingly stay away from steady-state conditions. To calculate the convergence speed can be calculated through:

Speed $=$ koefisien $\beta \times 100 \%$.

All data used in this study are primary data taken from the East Java and National Statistics Agency publications.

\section{RESULTS AND DISCUSSION}

In predicting the steady state conditions of economic growth in East Java, this study uses panel data with seris data for nine years, 2010-2018 and cross section data for 38 districts / cities in the East Java Province. Based on the results of the estimated regression using the panel data, the results of the convergence analysis of economic growth between districts / cities in East Java Province are presented in Table 1. 
Table 1: East Java Province Convergence Regression Results Panel Data

\begin{tabular}{lccc}
\hline \multirow{2}{*}{ VARIABLES } & $(1)$ & $(2)$ & $(3)$ \\
& OLS & FE & RE \\
\hline $1 Y$ & 2.335 & $-3.726^{* * *}$ & -0.405 \\
$1 \mathrm{PTB}$ & $(2.147)$ & $(0.719)$ & $(1.028)$ \\
& -1.318 & $0.992^{* *}$ & 0.981 \\
$1 \mathrm{NE}$ & $(2.278)$ & $(0.356)$ & $(1.189)$ \\
& 0.397 & $0.0752^{* * *}$ & $0.0388^{* *}$ \\
$1 \mathrm{AK}$ & $(0.315)$ & $(0.0202)$ & $(0.0168)$ \\
& 4.991 & $3.488^{* * *}$ & -0.254 \\
$1 \mathrm{MB}$ & $(2.735)$ & $(0.774)$ & $(0.947)$ \\
& -2.744 & $-0.773^{* * *}$ & -0.252 \\
$1 \mathrm{IPM}$ & $(2.222)$ & $(0.0905)$ & $(0.396)$ \\
& 0.0218 & 0.0122 & $-0.149^{*}$ \\
Constant & $(0.160)$ & $(0.0289)$ & $(0.0883)$ \\
& -18.54 & $23.35^{* * *}$ & 19.82 \\
& $(41.94)$ & $(4.013)$ & $(12.57)$ \\
\hline R-squared & & & \\
Number of kode & 0.418 & 0.953 & \\
F & & 9 & 9 \\
\hline
\end{tabular}

Standard errors in parentheses

*** $\mathrm{p}<0.01,{ }^{* *} \mathrm{p}<0.05,{ }^{*} \mathrm{p}<0.1$

Based on table 1 it can be explained that the most superior model between ordinary least sqaure and fixed effect is the fixed effect model through the chow test. This condition can be seen from the results of the analysis of the $p$ value of the fixed effect model below the significance value, which is equal to 0,000 . After a chow test, the next process is to do the Hausman test. While the results of the Hausman test are presented in table 2, below.

Tabel 2: Hausman Test convergence of East Java Province

\section{COEFFICIENTS}

B $\quad$ B $\quad(b-B) \quad$ Sqrt(diag(v_bv_B))

Fixed Effect Random Effect Difference S. E.

\begin{tabular}{lllll}
\hline IY & .0020213 & .0791413 & -.07712 &. \\
IPTM & .0216032 & .012696 & .0089072 &. \\
INE & -.0013834 & -.0035291 & .0021457 &. \\
IAK & .0733094 & .0065594 & .0667499 & .0811391 \\
IMB & -.0826333 & -.0898225 & .0071892 & - \\
IIPM & -.0533234 & -.0290177 & -.0243057 & .00352288 \\
\hline Chi2(1) & 27.38 & & & \\
Prob>chi2 & 0.0001 & & & \\
\hline
\end{tabular}

Based on table 2 it can be seen that the most superior model between fixed effects and random effects is the fixed effect model. This is because the 
result of $p$ value is smaller than the significance value, which is 0.0001 . So the model used in the analysis of this study is the fixed effect model.

The results of the convergence test of economic growth between regencies / cities in East Java Province presented in Table 1 explain that there were converging conditions during the study period. This can be seen in the intersest variable, which is negative per capita income which is $-3,726$ and is significant. That is, developing regions will be able to pursue the progress of rich regions. Therefore, developing regional income grows higher compared to rich regions. So that in the long run, developing regions in East Java Province will be able to pursue the progress of rich regions in East Java Province. This condition is in accordance with the concept of convergence which shows the hypothesis that each region has intrinsic potential to grow, if so then in a sufficiently long time there will be a condition in which each region will grow by itself. Areas that are initially less advanced will grow faster than other regions that have better initial conditions. In the end, the less developed regions will be able to catch up on more developed regions in such a way that growth and at the same time achieve equal distribution between regions (Mankiw, 2003).

The results of the convergence test in East Java Province are in accordance with the convergence theory hypothesis which states that if initial income is negatively correlated with economic growth, it can be interpreted that the economy in the region is more evenly distributed. These results, can be illustrated in Figure 1.

Figure 1: The Solow and Swan Model Convergence Hypothesis

Sources: Barrow dan Sala'i Martin, Economic Growth: Edition, 2004

\section{Steady State Value}

Based on the coefficient value of the variable interest can indicate how quickly the output per capita of an economy can reach a steady state point in a certain period. To know the steady state value, the speed of convergence calculation is needed as follows:

$\beta=\frac{(\ln (\mathrm{b}+1))}{T}$ 
Where, $b$ is the coefficient value of the intersest income per capita variable, while $\mathrm{T}$ is the number of research periods. Based on the calculation of the formula, the results obtained for $\beta=-0.048$. The results of the calculation of speed of convergence can explain that the speed of convergence in East Java Province is 4.8 percent. This result can be interpreted that regional income per capita in the province of East Java, especially developing regions must grow at least 4.8 percent per year so that the economy of East Java can reach a steady state point. To give an idea of what districts / cities need to be pushed to higher economic growth rates, we can see the following graphic image.

Figure 2. Regency / City Regional Economic Growth In East Java

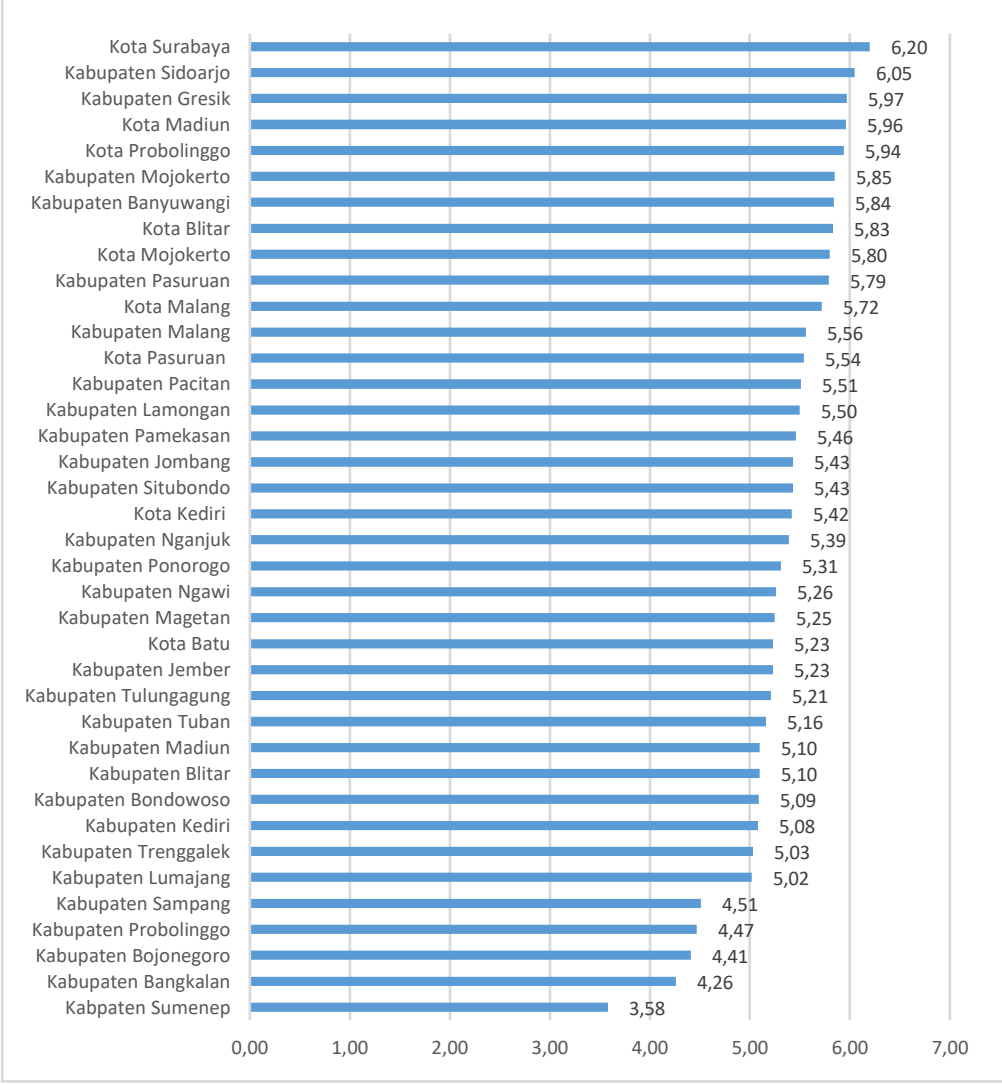

Sources: Jawa Timur Dalam Angka,2019, processed

In Figure 2 above, it can be seen that the regions that have the highest economic growth rates in East Java in 2018 are Surabaya City at $6.20 \%$, then followed by the Sidoarjo Regency, Gresik Regency with growth rates, each at $6.05 \%$ and $5.97 \%$. Whereas the regions with the lowest economic growth rates in East Java in 2018 were Sumenep Regency, namely 3.58\%, the second and third lowest were Bangkalan and Bojonegoro Districts, respectively $4.26 \%$ and $4.41 \%$.

By using the data reference above, developing regions or districts / cities with the lowest growth in East Java such as Sumenep, Bangkalan and Bojonegoro must be able to add an annual economic growth of $4.8 \%$ (speed of convergence) per year. Or in other words the three regions mentioned above

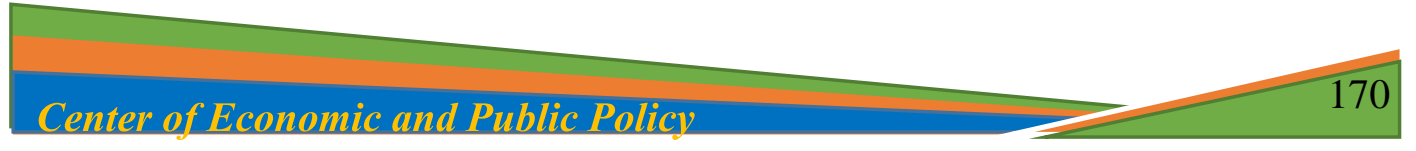


must grow 7 to $8 \%$ per year to pursue growth and per capita income of the City of Surabaya, Sidoarjo Regency, and Gresik Regency, if the area of East Java Province wants to achieve steady state conditions.

Meanwhile, to calculate how much time it takes for developing regions to achieve steady state conditions in East Java Province, the half-life of convergence value can be calculated which can be calculated with the following process.

$t=\frac{\ln (2)}{\beta}$

where $\beta$ is the value of speed of convergence, based on the results of calculations with the formula, the half-life of convergence value or $t$ value of 6.2 is obtained. Based on the results of the half-life of convergence calculation, the time needed to close half of the initial gap that occurred in East Java Province was 6.2 years. So, the time needed to cover the gap in per capita income between districts / cities in East Java takes 12.4 years with the condition or assumption that per capita income must increase by at least 4.8 percent.

In addition to predicting economic growth that must be achieved by the regions with the lowest economic growth to pursue the growth of the highest economic growth areas in East Java, this model also predicts the amount of time needed to catch up. The time prediction is analyzed based on several determinants of development growth which are included in endogenous variables in this model, namely: income per capita, gross fixed investment, net exports, labor force, capital expenditure, and human development index. So the value of the half-life of convergence of 6.2 years is based on the ability of these 6 variables to influence the economic growth of regency / city areas in East Java. Thus disadvantaged regions to pursue economic growth in developed regions in East Java, it must be able to improve the performance of these 6 variables. How much of each of these variables can drive economic growth in the regencies / cities in East Java will be discussed in the following section.

\section{Economic Growth Factors}

Table 1 for the fixed effect model also explains that the variable income per capita, gross fixed investment, net exports, the labor force, and capital expenditure have a significant effect on average economic growth. Because the value of $F$ of each variable is below the significance value. Variable gross fixed investment has a positive influence on economic growth in East Java Province with a value of 0.992 . This explains that every 1 percent increase in gross fixed capital investment can increase economic growth in East Java Province by 0.992 percent. The results of this study confirm the results of Andrian's research (2014), which analyzes the effect of Foreign Investment, Balancing Funds and Human Development Index on the growth of Gross Regional Domestic Product per capita in Indonesia after the implementation of regional autonomy in 2001-2012. The results of the study indicate that the variable Foreign Investment, balance funds and the Human Development Index positively influence the growth of Gross Regional Domestic Product per capita in Indonesia after the implementation of regional autonomy. This means that this 
study produces the same conclusions related to the condition of the national economic growth pattern with the pattern of economic growth in East Java which is influenced by investment factors.

The net export variable has a positive influence on economic growth in East Java Province worth 0.075 . That is, every 1 percent increase in net exports can increase economic growth in East Java Province by 0.075 percent. While the labor force variable also has a positive influence on economic growth, which is 3,488 . This indicates that every 1 percent increase in the labor force will be able to increase economic growth by 3,488 percent. These results are consistent with the research (Verawati, 2019), in his research which aims to analyze the effect of Government Expenditures, Household Consumption and Net Exports on Economic Growth as seen from the Gross Regional Domestic Product of Madura Island which consists of four districts namely Bangkalan, Sampang, Pamekasan, and Sumenep within a period of six years from 2011-2016. The results of the study, showed that Net Exports had a significant and positive effect on Gross Regional Domestic Product which had an impact on Economic Growth on Madura Island. Thus the study confirmed the results of this study, the results of which stated that net exports had a positive effect on the economic growth of East Java.

The variable capital expenditure also has a negative influence on economic growth, which is -0.773 . This means that every 1 percent increase in capital expenditure can reduce economic growth in East Java Province by 0.773 percent. The results of the capital expenditure variable have a negative correlation. This result is also in accordance with the results of the study (Verawati, 2019), which states the results that, Government Expenditures have no significant and negative effect. The similarity of the results of this study is that government spending has a negative effect on economic growth, should theoretically government expenditure (gaverment expenditure) has a positive effect on the value of output of economic growth. However, for the conditions of East Java and Madura, the opposite is true. This condition can be given an argument, because government spending in the form of development capital is still relatively small when compared to private capital, the average capital expenditure in regencies / cities in East Java is below 10\% of the total development investment in each region, that is what cause capital expenditure has no significant effect on economic growth in the area of East Java. What's more, if what happens is that capital expenditure that can reduce economic growth is when employee or routine expenditure is greater than the expenditure used to accelerate economic growth.

The human development index variable has no significant effect on economic growth in East Java Province with a coefficient value of 0.012. This result was rejected, because based on classical economic theory the human development index variable is one of the $\mathrm{K}$ values in the classical model of economic growth, namely human capital. The human development index is one of the important indicators in the development, and economic development in a region. 
All variables when viewed simultaneously, the independent variable has a contribution to economic growth of 95 percent. While the remaining 5 percent is influenced by other factor variables outside the equation model used.

\section{CONCLUSION}

Based on the results of the analysis, it can be concluded the following research findings. (a) economic growth between regencies / cities in East Java Province experienced convergent conditions during the study period. (b) per capita regional income that develops in Java Province must grow at least 4.8 percent per year so that the economy of East Java can reach a steady state point. (c) the time needed to close half of the initial gap that occurred in East Java Province was 6.2 years. (d) variable income per capita, gross fixed investment, net exports, labor force, and capital expenditure have a significant influence on the average economic growth.

By understanding the conditions of East Java's economic growth, a number of recommendations for East Java's economic development policies in the future include: (a) the provincial government strengthens coordination in an effort to strengthen collaboration between developed regions in the least developed regions. (b) explore and map the economic potential of each region in building the synergy of development planning, both from the central, provincial and district / city governments.

\section{REFERENCES}

Andrian Syah Malik, (2014). Analisis Konvergensi Antar Provinsi Di Indonesia Setelah Pelaksanaan Otonomi Daerah Tahun 2001-2012. JEJAK: Journal of Economics and Policy, Jejak 7 (1) (2014): 92-101. DOI: 10.15294/jejak.v7i1.3846.

Abramovitz, Moses. (1986). Catching Up, Forging Ahead, and Falling Behind. Journal of Economic History June 1986 pp. 385-405.

Badan Pusat Statistik Provinsi Jawa Timur. (2019). Tingkat Ketimpangan Pengeluaran Penduduk Provinsi Jawa Timur Maret 2019. No.46/07/35/Thn.XVII, 15 Juli 2019. Surabaya.

Badan Pusat Statistik Provinsi Jawa Timur. (2018). Provinsi Jawa Timur Dalam Angka 2018. No. Publikasi/Publication Number: 35560.1803. Surabaya.

Barro, R.J. dan X. Sala-i-Martin, (1992), "Convergence", Journal of Political Economy, 100(2), April: 223-51.

Barro, R.J. and Sala-i-Martin, X. (2004) Economic Growth. 2nd Edition, MIT, Cambridge

Beritajatim.com. (2019). Gubernur: Pemprov Jatim Lakukan 3 Intervensi Atasi Kemiskinan dan Kesenjangan Ekonomi. 15 April 2019. From: https://beritajatim.com/peristiwa/gubernur-pemprov-jatim-lakukan-3intervensi-atasi-kemiskinan-dan-kesenjangan-ekonomi/

Capello, Roberta. (2007). Regional Economics, Routledge.New York, Routledge. 
Gujarati, Damodar N., dan Dawn C. Porter. (2010). Dasar Dasar Ekonometrika. Buku 1. Terjemahan Eugenia Mardanugraha dkk. Jakarta: Salemba Empat.

Kementrian Keuangan RI. (2012). Tinjauan Ekonomi dan Keuangan Daerah. Jakarta: Kementrian Kuangan RI.

Kementrian Keuangan RI. (2019). Tinjauan Ekonomidan Keuangan Daerah. Jakarta: Kementrian Kuangan RI.

Kharisma, B., \& Saleh, S. (2013). Convergence of Income Among Province in Indonesia 1984 - 2008: A Panel Data Approach. Journal of Indonesian Economy and Business, 28 (2), 167- 187.

Kuncoro. 2013. "Mudah Memahami dan menganalisis Indikator ekonomi". Yogyakarta: UPP STIM YKPN.

Lall, S. dan S. Yilmaz, (2001), "Regional Economic Convergence: Do Policy Instruments Make a Difference?", Annals of Regional Science, 35(1), Februari: 153-55.

Mankiw, N. Gregory. (2003). Teori Makroekonomi (p.23). Edisi Kelima. Terjemahan Imam Nurmawan. Jakarta: Erlangga.

Mohtar Rasyid. (2017). Konvergensi Pendapatan Provinsi Jawa Timur: Pendekatan Panel Kota/Kabupaten Periode 20002013. Jurnal Ekonomi Kuantitatif Terapan Vol. 10 No. 2 Agustus 2017.

Prasasti, Diah. (2006). Perkembangan Produk Domestik Regional Bruto Per Kapita 30 Provinsi di Indonesia Periode 1993 - 2003: Pendekatan Kesenjangan Regional dan Konvergensi. Jurnal Ekonomi Bisnis Indonesia vol 21 No 6 Hal 364360.

Riatu, Q., (2002), "The Analysis of the Effect of Intergovernmental Transfer on Regional Economic Performance", Working Paper, International Studies Program, Andrew Young School of Policy Studies, Georgia University, http://www.isp-aysps. gsu.edu/papers/indonesia/riatu.pdf.

Shioji, Etsuro. (2001). Public Capital and Economic Growth: A Convergence Approach. Journal of Economic Growth, 6, 205-227. Netherlands. Kluwer Academic.

Verawati Fajrin, Heri S. (2019). Analisis Pertumbuhan Ekonomi Di Pulau Madura. Jurnal Ilmu Ekonomi-Qu. Volume. 9, No. 1, April 2019.

Wibisono, Yusuf. (2001). Determinan Pertumbuhan Ekonomi Regional: Studi Empiris Antar Propinsi Di Indonesia. Jurnal Ekonomi dan Pembangunan Indonesia. Vol. 1. No.2. Januari. 